\title{
Cytotoxicity and genotoxicity of calcium silicate-based cements on an osteoblast lineage
}

\section{Ana Lívia GOMES-CORNÉLIO(a) Elisandra Márcia RODRIGUES(a) Leticia Boldrin MESTIERI(a) Thaís de Oliveira Rodrigues Sanzovo FALCOSKI(b) Christiane Pienna SOARES(b) Juliane Maria GUERREIRO-TANOMARU(a) Carlos ROSSA JUNIOR(c) Mário TANOMARU-FILHO(a)}

(a)Universidade Estadual Paulista - UNESP, Araraquara School of Dentistry, Department of Restorative Dentistry, Araraquara, SP, Brazil.

(b) Universidade Estadual Paulista - UNESP, School of Pharmaceutical Sciences, Department of Clinical Analysis, Araraquara, SP, Brazil.

(c)Universidade Estadual Paulista - UNESP, Araraquara School of Dentistry, Department of Diagnosis and Surgery, Araraquara, SP, Brazil.

Declaration of Interests: The authors certify that they have no commercial or associative interest that represents a conflict of interest in connection with the manuscript.

Corresponding Author:

Mario Tanomaru-Filho

E-mail: tanomaru@uol.com.br

DOI: 10.1590/1807-3107BOR-2016.vol30.0048

Submitted: Sep 23, 2015

Accepted for publication: Jan 27, 2016

Last revision: Feb 17, 2016
Abstract: Several calcium silicate-based biomaterials have been developed in recent years, in addition to Mineral Trioxide Aggregate (MTA). The aim of this study was to evaluate the cytotoxicity, genotoxicity and apoptosis/necrosis in human osteoblast cells (SAOS-2) of pure calcium silicate-based cements (CSC) and modified formulations: modified calcium silicate-based cements (CSCM) and three resin-based calcium silicate cements (CSCR1) (CSCR 2) (CSCR3). The following tests were performed after 24 hours of cement extract exposure: methyl-thiazolyl tetrazolium (MTT), apoptosis/necrosis assay and comet assay. The negative control (CT-) was performed with untreated cells, and the positive control (CT+) used hydrogen peroxide. The data for MTT and apoptosis were submitted to analysis of variance and Bonferroni's posttest ( $p<0.05)$, and the data for the comet assay analysis, to the Kruskal-Wallis and Dunn tests $(\mathrm{p}<0.05)$. The MTT test showed no significant difference among the materials in $2 \mathrm{mg} / \mathrm{mL}$ and $10 \mathrm{mg} / \mathrm{mL}$ concentrations. CSCR3 showed lower cell viability at $10 \mathrm{mg} / \mathrm{mL}$. Only CSC showed lower cell viability at $50 \mathrm{mg} / \mathrm{mL}$. CSCR1, CSCR2 and CSCR3 showed a higher percentage of initial apoptosis than the control in the apoptosis test, after 24 hours exposure. The same cements showed no genotoxicity in the concentration of $2 \mathrm{mg} / \mathrm{mL}$, with the comet assay. CSC and CSCR2 were also not genotoxic at $10 \mathrm{mg} / \mathrm{mL}$. All experimental materials showed viability with MTT. CSC and CSCR2 presented a better response to apoptosis and genotoxicity evaluation in the $10 \mathrm{mg} / \mathrm{mL}$ concentration, and demonstrated a considerable potential for use as reparative materials.

Keywords: Cytotoxicity, Immunologic; Mutagenicity Tests; Calcium Compounds.

\section{Introduction}

An innovative repair material was developed in 1993 at the University of Loma Linda, called Mineral Trioxide Aggregate (MTA). ${ }^{1}$ MTA has been used successfully for apexification, internal root resorption, endodontic surgery, sealing of perforations, and as a pulp-capping material. ${ }^{2}$ Fine particles of tricalcium silicate, tricalcium aluminum, tricalcium oxide and other oxide materials, in addition to bismuth oxide, which promotes the radiopacity of cement, make up the composition of MTA powder, which sets on contact with water. ${ }^{3}$ MTA is a non-cytotoxic reparative material 
with excellent biological properties. ${ }^{4}$ MTA contributes to reducing inflammation and necrosis levels. The use of MTA as pulp-capping material induces the formation of a dentin bridge, allowing repair and pulp vitality. ${ }^{5}$ Various studies have shown that the physicochemical and biological properties of MTA are similar to those of Portland Cement (PC), a calcium silicate-based cement (CSC). ${ }^{6,7}$

Calcium silicate based cements (CSC) have the potential to stimulate cell proliferation and osteoblast-related gene expression in osteoblasts. ${ }^{8,9}$ Anti-inflammatory effects and dentinogenic potential have been observed in primary pulp cells and mouse dental papilla cell-23 (MDPC-23) cells exposed to CSC cements, respectively. ${ }^{10,11}$

The fluid and granular consistency of MTA and its elevated setting time make its clinical use difficult. Additives are used to increase the plasticity of CSCs, and thus facilitate material handling. ${ }^{12}$ Different formulations of this cement, modified with additives and resins, have been proposed to improve the manipulation and consistency of the cement, and have ultimately given rise to modified calcium silicate cements (CSCMs) and resin calcium silicate cements (CSCRs). The addition of $2 \%$ and $5 \%$ calcium chloride to Portland cement has promoted better setting times, and a biocompatibility similar to that of MTA. ${ }^{13} \mathrm{~A}$ newly proposal material called calcium silicate-gelatin cement has presented a better setting time, work time and flow than MTA ProRoot. This material has also provided suitable results in regard to proliferation and differentiation of dental pulp cells. ${ }^{14}$

Bosso-Martelo et al..$^{15}$ evaluated the physicochemical properties of calcium silicate cements with additives and resins. Some combinations of silicate-based cements and different radiopacifiers have provided a shorter final setting time, low solubility, alkaline $\mathrm{pH}$ and calcium ion release. In a recent study, the addition of fluoride-containing radiopacifier ytterbium trifluoride ( $\mathrm{YbF}$ ) improved the micromechanical and biological characteristics of modified calcium silicate cements, without modifying osteoclast and osteoblast-like cell integrity. ${ }^{16}$

The biological properties of new cement formulations must be studied for possible application in dentistry. Reparative materials used in contact with periodontal or pulp tissues should not present cytotoxicity or genotoxicity, thereby favoring the repair process. ${ }^{17,18}$ Genotoxicity describes the property of a chemical agent that damages the genetic information within a cell, causing mutations. Ribeiro et al. ${ }^{19}$ also showed that regular and white mineral trioxide aggregate (MTA) cements presented no cytotoxicity and genotoxicity when mouse lymphoma cells were exposed to them, according to the trypan blue and comet assays, respectively. Similar results with Portland cement have shown that none of these materials were cytotoxic when evaluated alone or in association with radiopacifying agents. ${ }^{20,21}$

The aim of this study was to investigate whether the new formulations of pure and modified calcium silicate-based cements induced some type of damage to human osteosarcoma cells (Saos-2). The MTT and apoptosis assays were performed on cement extracts, and the genotoxicity effects were evaluated by comet assay, to monitor the cytotoxic effects.

\section{Methodology}

\section{Cell Culture}

Human osteoblast cells (SAOS-2 line ATCC HTB85) were grown as a monolayer culture in T-75 flasks (Corning, Union City, USA) containing Dulbecco Modified Eagle Medium (DMEM-Sigma/Aldrich, St. Louis, USA) supplemented with $10 \%$ fetal bovine serum (FBS), penicillin (100 IU/mL), and streptomycin (100 $\mathrm{mg} / \mathrm{mL}$ ) until confluent. The cells were subcultured twice a week at $37{ }^{\circ} \mathrm{C}, 95 \%$ humidity and $5 \% \mathrm{CO}_{2}$. Adherent cells in logarithmic growth phase were detached by a mixture of trypsin/EDTA $(0.25 \%)$ at $37^{\circ} \mathrm{C}$ for 3 minutes.

\section{Preparation of extracts}

The study procedure followed the methodology described by Gomes-Cornélio et al. ${ }^{21}$ One gram of each experimental cement was weighed and manipulated with distilled water, in the recommended proportions, on sterile glass plates (Table). After manipulation, the materials were weighed $(1 \mathrm{~g})$ again, and placed in $50 \mathrm{~mL}$ Falcon tube lids. All the materials were duly identified, imbibed with damp sterile gauze and taken to the laminar flow chamber, where they 
remained for 30 minutes under UV light to prevent contamination. After this period, the Falcon tubes were filled with $10 \mathrm{~mL}$ of DMEM culture medium containing 10\% FBS, the cement-filled lids were fitted onto each tube, which was inverted, so that the materials would come into contact with the culture medium; the tubes were then placed in an oven at $37^{\circ} \mathrm{C}, 95 \%$ humidity and $5 \% \mathrm{CO}_{2}$, for 3 hours. Three eluates were selected, as recommended by a previous study, ${ }^{21}$ and prepared after contact of the materials with the culture medium: $50 \mathrm{mg} / \mathrm{mL}, 10 \mathrm{mg} / \mathrm{mL}$ and $2 \mathrm{mg} / \mathrm{mL}$ before cell exposure.

\section{MTT assay}

This assay consists of determining how well the mitochondrial dehydrogenase enzyme converts the water-soluble yellow salt [3-(4,5-dimethyl-thiazoyl)2,5-diphenyl-tetrazolium bromide - MTT; Sigma/ Aldrich] into colored formazan compounds, whose absorbance is proportional to the quantity of live cells. A number of $1 \times 10^{5}$ cells $/ \mathrm{mL}$ were plated in 24-well culture plates, in triplicate.

After remaining 24 hours in the cell culture with the 3 different eluates of each cement and the controls ( $\mathrm{C}+$ : $3 \%$ hydrogen peroxide, and C-: negative control = cells without treatment), the eluates were aspired and replaced with $900 \mu \mathrm{l}$ of D-MEM and $5 \mathrm{mg} / \mathrm{mL}$ MTT salt, and the plates were incubated for an additional $3 \mathrm{~h}$, in an oven at $37^{\circ} \mathrm{C}, 95 \%$ humidity and $5 \% \mathrm{CO}_{2}$. After this period, each well was washed with $1 \mathrm{~mL}$ of phosphate buffer (PBS 1X) and aspirated. Then $500 \mu \mathrm{l}$ of acidified isopropyl alcohol ( $\mathrm{HCl}$ : isopropyl alcohol, $0.04 \mathrm{~N}$ ) was added to the extract to solubilize the formazan crystals. The samples were transferred to a 96-well plate for readout in triplicate.

The optical density (OD) was measured by an automatic microplate reader (ELx800; BioTek Instruments, Winooski, USA) and submitted to statistical analysis by the variance test (ANOVA), with Bonferroni's posttest $(p<0.05)$. Three repetitions of the experiment were performed.

\section{Comet assay}

\section{Preparation of Slides}

A number of $2 \times 10^{6}$ cells $/ \mathrm{mL}$ were plated in 24-well culture plates, in triplicate. After 24 hours, the cells were exposed to the 3 different cement eluates and kept in an oven at $37^{\circ} \mathrm{C}, 95 \%$ humidity and $5 \% \mathrm{CO}_{2}$, for an additional 24 hours. The experiment was based on the technique described by Sigh et al. ${ }^{22}$ After treatment of the cells with the different cement extracts, 200 $\mu \mathrm{l}$ of trypsin/0.25\% EDTA (Sigma/Aldrich) was added to each well of the plate for $2 \mathrm{~min}$ to detach the cells. After centrifugation (2000 rpm/3 min), each group of cells was resuspended in $200 \mu \mathrm{l}$ of agarose LMP (low melting point, Sigma/Aldrich) and transferred to slides recently prepared with $1.5 \%$ agarose (Sigma/Aldrich). The slides were immersed in lysis solution $(\mathrm{NaCl} 2.5 \mathrm{M}$, EDTA $100 \mathrm{mM}$, Tris $10 \mathrm{mM} / 1 \%$ Triton X-100, 10\% DMSO) and kept at $4{ }^{\circ} \mathrm{C}$ overnight. SAOS-2 cells treated with $\mathrm{H}_{2} \mathrm{O}_{2}(1 \mathrm{mM})$ were used as the positive control.

\section{Electrophoresis}

The prepared slides were organized in a horizontal electrophoresis cube, and left in the electrophoresis solution (10 mL 0.2M EDTA + $60 \mathrm{~mL} 10 \mathrm{M} \mathrm{NaOH}, \mathrm{pH} 13$, to complete $2000 \mathrm{~mL}$ milliQ $\mathrm{H}_{2} 0$ ) for 20 minutes to allow DNA unwinding. The source was set to $25 \mathrm{~V}$, and the run continued for another 20 minutes. The slides were removed, immersed in a neutralizing solution (0.4M Tris $\mathrm{pH} 7.5$ ) for $15 \mathrm{~min}$, fixed in pure ethanol, and left to dry at room temperature.

\section{Staining and Analysis}

An $80 \mu$ l volume of ethidium bromide $(0.02 \mathrm{mg} / \mathrm{mL})$ was added to stain the slides, and the readouts were immediately taken under a fluorescence microscope (Nikon Corporation, Tokyo, Japan) at 400x magnification. Counts of 100 cells/group were made, and each selected field was photographed. The images were analyzed in the Comet Score software program, and statistically analyzed by the Graphpad Prism 5.03 software program. The counted cells were analyzed, and the same group of materials was compared with both the positive and the negative controls.

The Kruskal-Wallis and Dunn $(p<0.05)$ tests were performed for the purpose of statistical analysis.

\section{Apoptosis Assay}

A number of $1 \times 10^{6}$ SAOS- 2 cells were plated on 24-well culture plates, after remaining in contact 
Table. Experimental materials, source and proportions used.

\begin{tabular}{|c|c|}
\hline Material & Manufacturer \\
\hline \multirow{2}{*}{ Calcium Silicate Cement (CSC) } & Votorantin Cimentos, Camargo Correa Cimentos S.A., Pedro Leopoldo, MG, Brazil \\
\hline & Proportion: $1 \mathrm{~g}: 0.36 \mathrm{~mL}$ \\
\hline \multirow{2}{*}{ Modified Calcium Silicate Cement (M)* } & Usina Fortaleza ICMF Ltda., Barueri, SP, Brazil \\
\hline & Proportion: $1 \mathrm{~g}: 0.25 \mathrm{~mL}$ \\
\hline \multirow{2}{*}{ Resin Calcium Silicate Cement (CSCR)** } & Usina Fortaleza ICMF Ltda., Barueri, SP, Brazil \\
\hline & Proportion: $1 \mathrm{~g}: 0.36 \mathrm{~mL}$ \\
\hline \multirow{2}{*}{ Resin Calcium Silicate Cement 2 (CSCR2)** } & Ligatex Ind. e Com. Ltda., Rio Claro, SP, Brazil \\
\hline & Proportion: $1 \mathrm{~g}: 0.28 \mathrm{~mL}$ \\
\hline \multirow{2}{*}{ Resin Calcium Silicate Cement 3 (CSCR3)* } & Cimentolit Ind. e Com. Ltda., Charqueada, São Paulo, Brazil \\
\hline & Proportion: $1 \mathrm{~g}: 0.30 \mathrm{~mL}$ \\
\hline
\end{tabular}

*Composition: mineral aggregates, additives and pigments; ${ }^{* *}$ Composition: mineral aggregates, resins, additives and pigments.

with the cement eluates $(10 \mathrm{mg} / \mathrm{mL})$. The test was performed with the FITC Annexin V Apoptosis Detection Kit I (BD Biosciences, Pharmingen, San Jose, USA) in a 24-hour period. Afterwards, the cells were washed and collected from the culture plate wells containing nonenzymatic reagent (cell dissociation buffer - Gibco/Carlsbad, California, USA), resuspended in binding buffer $1 \mathrm{X}(0.1 \mathrm{M}$ Hepes/NaOH; $1.4 \mathrm{M} \mathrm{NaCl} ; 25 \mathrm{mM} \mathrm{CaCl}{ }_{2}$ pH: 7.4), and then stained with apoptosis markers: FITC Annexin V and/or PI (propidium iodide staining solution) - $50 \mu \mathrm{g} / \mathrm{mL}$; these same cells also underwent unmarked controls and the positive control (Camptothecin 1mM- Sigma/Aldrich). All the Eppendorf tubes were incubated in a dark environment for $15 \mathrm{~min}$, and $400 \mu \mathrm{l}$ of $1 \mathrm{X}$ binding buffer was added to each sample. Analyses were performed in a Flow Cytometer (BD FACS Verse 4C), in accordance with the parameters of the kit: viable cells (FITC-/ PI-); cells at the stage of initial apoptosis (FITC+/ PI-); cells at the stage of final apoptosis (FITC+/ PI+); cellular necrosis (FITC -/ PI+). The results were submitted to statistical analysis of variance (ANOVA), with Bonferroni's posttest $(p<0.05)$. The experiment was conducted in triplicate.

\section{Results}

\section{MTT assay}

The cements evaluated presented biocompatibility, with results similar to those of the negative control group ( $\mathrm{p}<0.05$ ), except for CSC $50 \mathrm{mg} / \mathrm{mL}$ and CSCR3 $10 \mathrm{mg} / \mathrm{mL}$, as shown in Figure 1.

\section{Comet Assay}

All of the CSCs evaluated, with the exception of the pure CSC, presented genotoxicity in the concentration of $50 \mathrm{mg} / \mathrm{mL}$, compared with the control, whereas CSC and CSCR2 presented no genotoxicity in the concentration of $10 \mathrm{mg} / \mathrm{mL}$, compared with the negative control. In the last concentration of $2 \mathrm{mg} / \mathrm{mL}$, all the cements, except for CSCM, were similar to those of the negative control group $(p<0.05)$, (Figure 2$)$.

\section{Apoptosis Assay}

Histograms were used to represent the percentage of viable osteoblast cells (SAOS-2), and analyze the initial and final stage of apoptosis and necrosis, within a 24-hour period. In regard to cell viability, groups CSCR1 and CSCR2 were found to be similar to the negative control (cells without treatment), unlike CSCR3, which displayed low cell viability $(\mathrm{p}<0.05)$. Groups CSC and CSCM presented slightly higher viability values than those of the negative control. In the initial stage of apoptosis, all the groups were found to be different from the negative control, with higher percentages, and the CSCR3 group showed a higher rate of initial apoptosis $(p<0.05)$. The experimental groups showed lower values of late apoptosis and necrosis, compared with the negative control $(p<0.05)$, (Figure 3). 


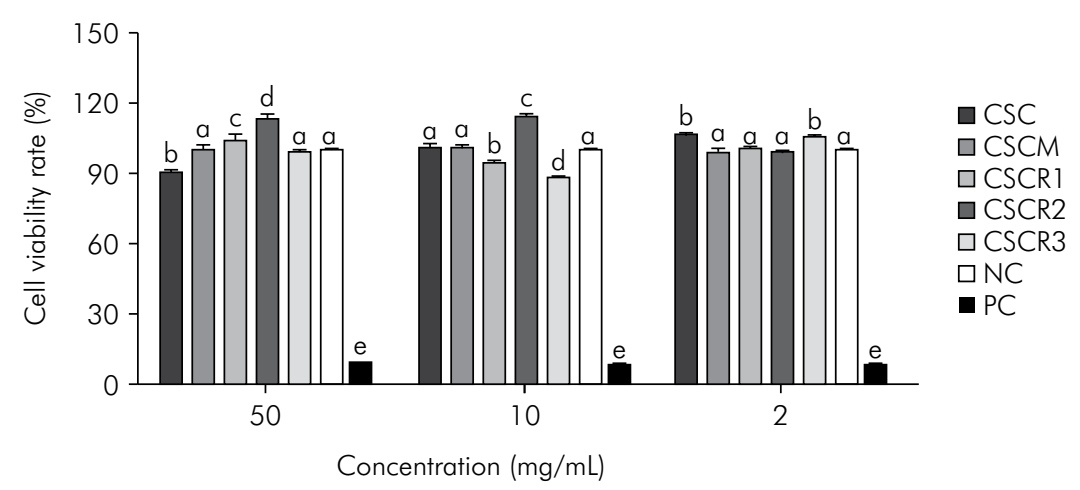

Figure 1. Cell viability of SAOS-2, after being cultivated with eluates of the cements in different concentrations $(50 \mathrm{mg} / \mathrm{mL} ; 10 \mathrm{mg} / \mathrm{mL}$; $2 \mathrm{mg} / \mathrm{mL}$ ) in a period of 24 hours. NC represents the negative control (untreated cells), and PC represents the positive control (3\% hydrogen peroxide) for 10 minutes. Different letters represent results that differed statistically among one another, within the same concentration. Analysis of Variance, Bonferroni $(p<0.05)$.

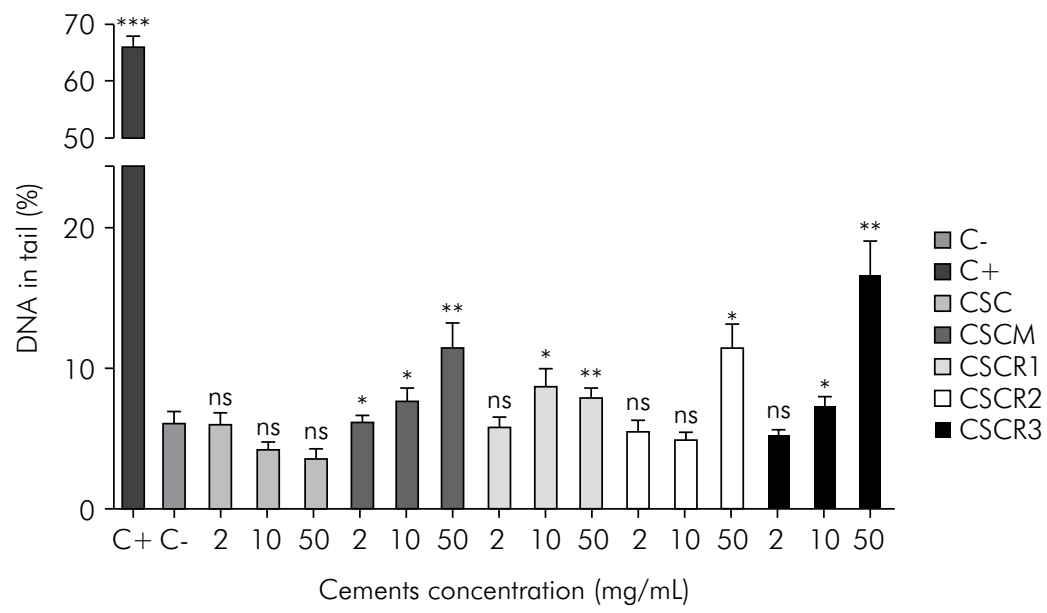

$*_{p}<0.05$

$*^{* *} p<0.01$

$* * * p<0.001$.

Figure 2. Genotoxicity represented by $\%$ of DNA in the tail, in the SAOS-2 cell lineage treated with eluates of $50,10 \mathrm{and} 2 \mathrm{mg} / \mathrm{mL}$ for 24 hours. C-: Negative control (untreated cells), C+: Positive control (1 mM of hydrogen peroxide for $10 \mathrm{~min})$. Results are expressed as a \% of DNA in the tail of 100 cells per concentration and controls, and analyzed by Kruskal-Wallis, with the Dunn posttest (treated vs. C-).

\section{Discussion}

Additives have been incorporated into Portland cement to improve its physical and chemical properties. New calcium silicate-based cements have also been studied, ${ }^{23,24}$ and some of the modified calcium silicate and resin cements under study may present the potential for clinical use. CSCM is a modified calcium silicate cement that contains mineral aggregates, additives and pigments. Resin calcium silicate cements (CSCRs) not only have mineral aggregates, additives and pigments, but also resin components in their composition, aimed at improving their manipulation and setting time. However, the addition of composites in cements may interfere and harm their biological properties and bioactivity. ${ }^{13}$

The immortalized osteoblast cell lineage was used in this study, because of its reproducibility capabilities, and because its relationship with the bone repair process in tissues ${ }^{25,26}$ makes it ideal for vitro assays researching new endodontic and retrofilling materials. Modareszadeh et al. ${ }^{27}$ evaluated 


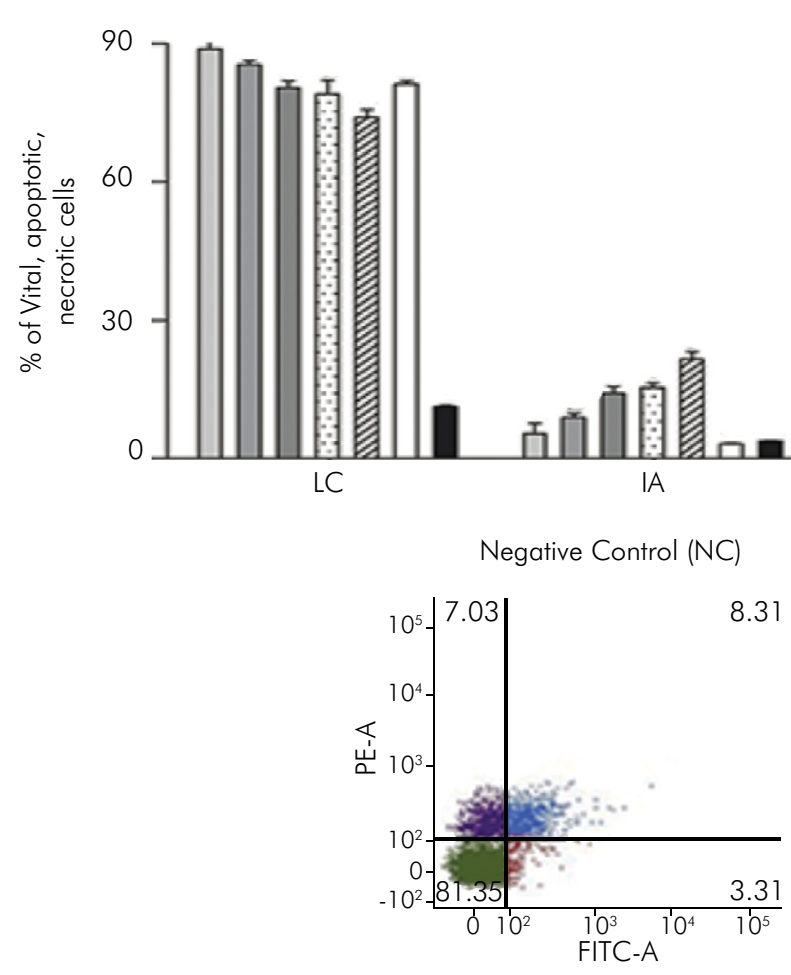

CSC
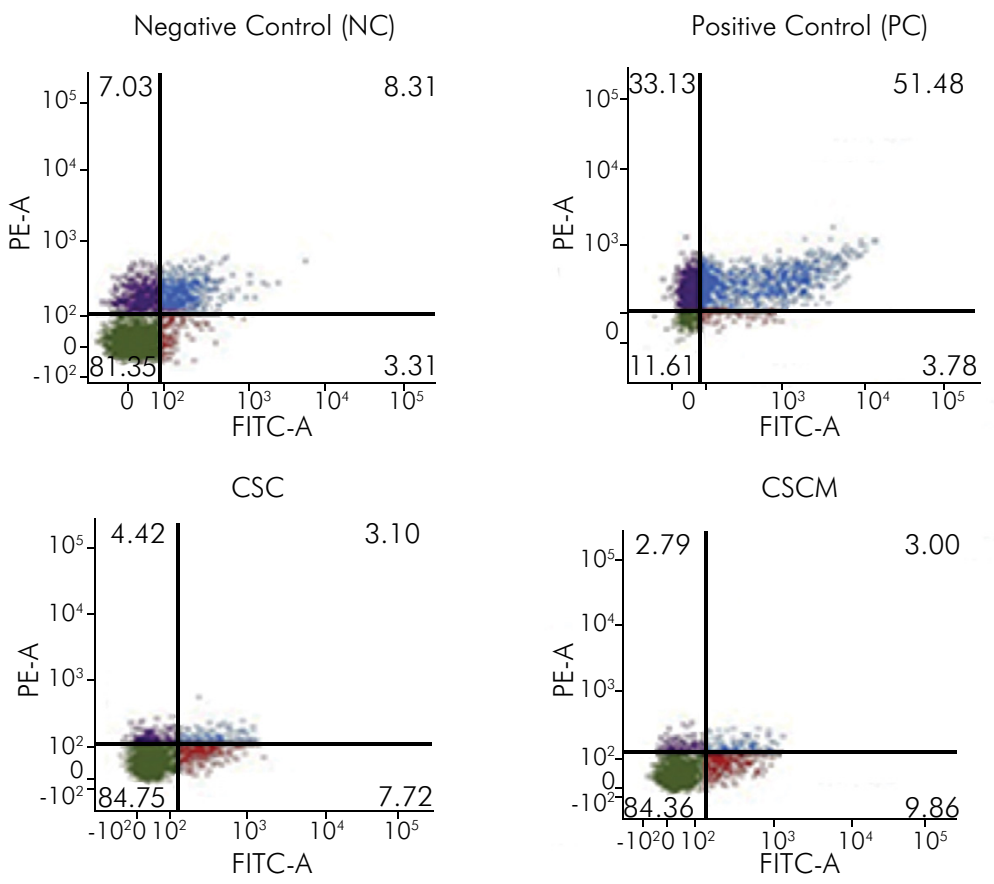

CSCR 1

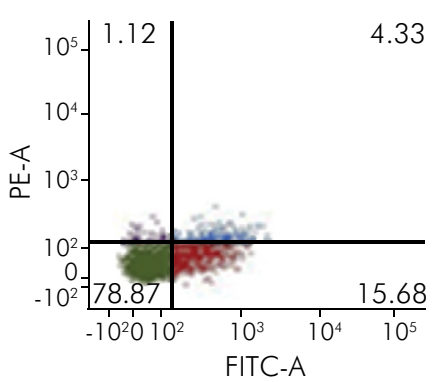

CSCR2

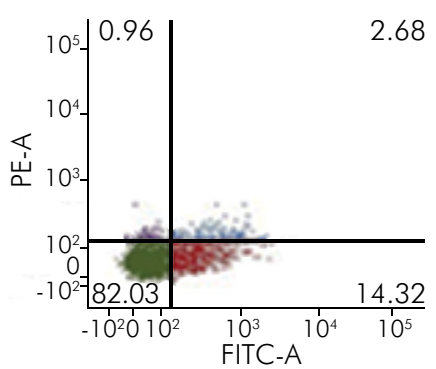

CSCR3

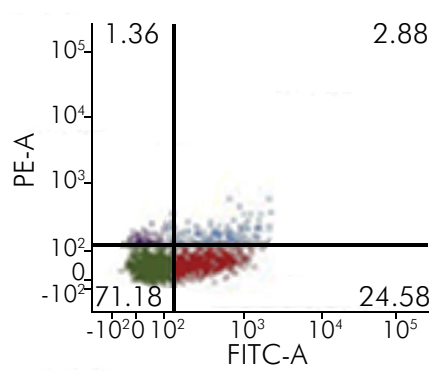

Figure 3. (A) Flow cytometry analysis of SAOS-2 viability, mortality by apoptosis or necrosis after exposure to different calcium silicate-based cements on the concentration of $10 \mathrm{mg} / \mathrm{mL}$ after 24 hours. Cells exposed to medium were the negative control and cells treated with hydrogen peroxide $(1 \mathrm{mM})$ were the positive control group. (B) Representative 2-dimensional flow cytometry dot plot of data derived from FITC-AnV and PE incorporated PI stained SAOS-2 cells of control, CSC, CSCM, CSCR1, CSCR2 and CSCR3 groups. Bars with different letters represent significant differences between groups in each population analyzed. The population of living cells (LC) (annexin-/ PI-), initial apoptosis (IA) (annexin+/ PI-), late apoptosisor secondary necrosis (LA) (annexin+/ PI+), and necrotic $(\mathrm{N})$ (annexin-/ $\mathrm{PI}+$ )cells are represented in the left inferior, right inferior, right superior and left superior quadrants, respectively. $\mathrm{PC}=$ positive control, $\mathrm{NC}=$ negative control. 
the cytotoxicity and bioactivity of the Endo sequence bioceramic material (Brasseler, Savannah, USA) in human osteoblast cells (SAOS-2), and reported the importance of these cells in the mineralization and repair process. Gandolfi et al. ${ }^{28}$ confirmed that calcium silicate-based cements and MTA are good substrates for osteoblast growth, and induce cell proliferation, even when fresh cements are used, as was done in the present study.

The results of the present study showed that calcium silicate-based cements did not present cytotoxicity, compared with the positive control ( $3 \%$ hydrogen peroxide), and were similar to the negative control (untreated cells) particularly in the concentrations of $10 \mathrm{mg} / \mathrm{mL}$ and $2 \mathrm{mg} / \mathrm{mL}$. Favorable results have been observed for pure and/or modified calcium silicate-based cements, either associated with radiopacifying agents, or not. ${ }^{21,29}$ A newly developed CSC, with zirconium oxide $\left(\mathrm{ZrO}_{2}\right)$, named Ortho-MTA (OMTA; BioMTA, Seoul, Korea) has promoted an inflammatory response and odontoblastic differentiation similar to Biodentine and MTA Angelus in human dental pulp cells (hDPCs). ${ }^{30}$ Furthermore, CSC has been found to stimulate osteogenesis in a co-culture of macrophage cells (Raw 264.7) and osteoblast cells (MC3T3-E1), with improved proliferation and higher calcium deposition than cells in a monoculture. ${ }^{31}$ In our recent study, the silicate-based cement associated with $\mathrm{ZrO}_{2}$ exhibited a viability rate similar to that of MTA Plus and Biodentine in osteoblast-like cells. ${ }^{32}$ However, the MTT assay could show a false-positive result, ${ }^{33}$ thus making it important to perform other cytotoxicity tests.

Some studies have shown that MTA does not induce significant apoptosis and/or necrosis in distinct cell lineages. ${ }^{33,34}$ The flow cytometry experiment using the FITC Annexin V Apoptosis Detection Kit I (BD Biosciences) was used to analyze the following: intact cells; cells in initial apoptosis, where FITC binds to phosphatidylserine (a component of the cell membrane), which is found inverted in the cells at this stage; and cells in final apoptosis and necrosis. In this final stage, in addition to the positive binding of FITC, there is also the binding of PI (propidium iodide) to the genetic material of the cell, since the membrane is completely damaged at this stage of cell death, thus allowing entry of the marker. Gorduysus et al. ${ }^{35}$ used the same methodology to evaluate the type of cell death of human fibroblasts in different endodontic materials. MTA behaved in a manner very similar to that of the control, with high percentages of viable cells; however, the materials tested [Diaket (ESPE, Seefeld, Germany) Endion (VOCO, Cuxhaven, Germany) and CYMED 8410 (NANO, Kaohsiung, Taiwan)] induced high percentages of apoptosis and necrosis, in comparison with the control.

CSCR1 and CSCR2 were similar to the control as regards cell viability, unlike CSCR3, which had a lower percentage of cell viability $(p<0.05)$. Groups CSC and CSCM presented higher viability values than those of the negative control $(p<0.05)$. All the experimental groups induced initial apoptosis, but not late apoptosis or necrosis, compared with the control $(\mathrm{p}<0.05)$. It is known that endoplasmic reticulum stress caused by an excess of $\mathrm{Ca}^{+2}$ ions may lead to apoptosis; ${ }^{36}$ this could be one of the explanations for why the groups treated with different calcium silicate-based cements had a rapid onset of apoptosis. Eid et al. ${ }^{37}$ also found a higher percentage of apoptosis in cells exposed to the calcium silicate-based MTA Plus and MTA Angelus materials, suggesting that the initial sites of irreversible damage by cytotoxic agents are extracellular, while the nuclear membranes of these cells still remain intact.

The comet assay suggested damage to DNA, chromosome breakage, altered DNA repair and cellular transformation. ${ }^{20}$ Among the various parameters calculated by this method, one of the most widely used indicators of DNA damage is the length of the comet tail, which is a virtual measurement calculated by the computed image analysis system, considering both the duration of DNA migration in the comet tail and the intensity of the tail. ${ }^{38}$

The results of this study revealed that CSC and CSCR2 performed outstandingly in the concentration of $10 \mathrm{mg} / \mathrm{mL}$, since they presented no genotoxicity compared with the negative control. These results for pure CSC corroborate those of other studies that have demonstrated its biocompatibility. ${ }^{19,20,21}$ The 
low genotoxic risk associated with a new cement based on dicalcium- and tricalcium-silicate (CS) with hydroxyapatite (HA) was observed using the comet assay and human peripheral blood lymphocytes. ${ }^{39}$ Biosilicate ${ }^{\circledR}$ analysis of genotoxicity showed no DNA damage in lineages, osteoblasts or fibroblasts, in all the evaluation periods $(24,72$, and 96 hours). ${ }^{40}$

The different modified CSCs presented appropriate cell viability results. A high number of living cells were preserved in the cells exposed to CSCs, although the percentage of apoptosis increased slightly.

\section{References}

1. Torabinejad M, Watson TF, Pitt Ford TR. Sealing ability of a mineral trioxide aggregate when used as a root end filling material. J Endod. 1993;19(12):591-5. doi:10.1016/S0099-2399(06)80271-2

2. Torabinejad M, Parirokh M. Mineral trioxide aggregate: a comprehensive literature review - part II: leakage and biocompatibility investigations. J Endod. 2010 Feb;36(2):190-202. doi:10.1016/j.joen.2009.09.010

3. Tanomaru-Filho M, Bosso R, Viapiana R, Guerreiro-Tanomaru JM. Radiopacity and flow of different endodontic sealers. Acta Odontol Latinoam. 2013;26(2):121-5.

4. Pelliccioni GA, Ciapetti G, Cenni E, Granchi D, Nanni M, Pagani S, et al. Evaluation of osteoblast-like cell response to Proroot MTA (mineral trioxide aggregate) cement. J Mater Sci Mater Med. 2004;15(2):167-73. doi:10.1023/B:JMSM.0000011819.26935.47

5. Bogen G, Kim JS, Bakland LK. Direct pulp capping with mineral trioxide aggregate: an observational study. J Am Dent Assoc. 2008;139(3):305-15; quiz 305-15. Erratum in: J Am Dent Assoc. 2008;139(5):541.

6. Oliveira MG, Xavier CB, Demarco FF, Pinheiro AL, Costa AT, Pozza DH. Comparative chemical study of MTA and Portland cements. Braz Dent J. 2007;18(1):3-7. doi:10.1590/S0103-64402007000100002

7. Gonçalves JL, Viapiana R, Miranda CE, Borges AH, Cruz Filho AM. Evaluation of physico-chemical properties of Portland cements and MTA. Braz Oral Res. 2010;24(3):277-83. doi:10.1590/S1806-83242010000300004

8. Maeno S, Niki Y, Matsumoto H, Morioka H, Yatabe $\mathrm{T}$, Funayama A, et al. The effect of calcium ion concentration on osteoblast viability, proliferation and differentiation in monolayer and 3D culture. Biomaterials. 2005;26(23):4847-55. doi:10.1016/j. biomaterials.2005.01.006
Genotoxicity analysis indicated that the CSCs did not induce DNA damage in osteoblast-like cells (Saos-2) at the highest CSC dilution. These results suggest that CSCs have a good potential for use as a reparative material. However, additional studies are needed to research new CSCs.

\section{Acknowledgements}

This study received financial support from the Fundação de Amparo à Pesquisa do Estado de São Paulo-FAPESP, process no. 2011/13116-1, 2011/18239-4 and 2012/13268-9.
9. Sun J, Wei L, Liu X, Li J, Li B, Wang G, et al. Influences of ionic dissolution products of dicalcium silicate coating on osteoblastic proliferation, differentiation and gene expression. Acta Biomater. 2009;5(4):1284-93. doi:10.1016/j.actbio.2008.10.011

10. Eid AA, Niu L-n, Primus CM, Opperman LA, Watanabe I, Pashley DH, et al. In vitro osteogenic/ dentinogenic potential of an experimental calcium aluminosilicate cement. J Endod. 2013;39(9):1161-6. doi:0.1016/j.joen.2013.04.005

11. Chen CL, Kao CT, Ding SJ, Shie MY, Huang TH. Expression of the inflammatory marker cyclooxygenase- 2 in dental pulp cells cultured with mineral trioxide aggregate or calcium silicate cements. J Endod. 2010;36(3):465-8. doi:10.1016/j.joen.2009.12.008

12. Bortoluzzi EA, Broon NJ, Bramante CM, Garcia RB, Moraes IG, Bernardineli N. Sealing ability of MTA and radiopaque Portland cement with or without calcium chloride for root-end filling. J Endod. 2006;32(9):897-900. doi:10.1016/j.joen.2006.04.006

13. Bramante CM, Kato MM, Assis GF, Duarte MA, Bernardineli N, Moraes IG, et al. Biocompatibility and setting time of CPM-MTA and white Portland cement clinker with or without calcium sulfate. J Appl Oral Sci. 2013;21(1):32-6. doi:10.1590/1678-7757201302200

14. Wang CW, Chiang TY, Chang HC, Ding SJ. Physicochemical properties and osteogenic activity of radiopaque calcium silicate-gelatin cements. J Mater Sci Mater Med. 2014;25(9):2193-203. doi:10.1007/s10856-014-5258-5

15. Bosso-Martelo R, Guerreiro-Tanomaru JM, Viapiana R, Berbert FLC, Duarte MAH, Tanomaru-Filho M. Physicochemical properties of calcium silicate cements associated with microparticulate and nanoparticulate 
radiopacifiers. Clin Oral Investig. 2016 Jan;20(1):83-90. doi:10.1007/s00784-015-1483-7

16. Antonijevic D, Jeschke A, Colovic B, Milovanovic P, Jevremovic D, Kisic D, et al. Addition of fluoridecontaining radiopacifier improves micromechanical and biological characteristics of modified calcium silicate cements. J Endod. 2015;41(12):2050-7. doi:10.1016/j.joen.2015.09.008

17. Borra RC, Lotufo MA, Gagioti SM, Barros FM, Andrade PM. A simple method to measure cell viability in proliferation and cytotoxicity assays. Braz Oral Res. 2009;23(3):255-62. doi:10.1590/S1806-83242009000300006

18. Willershausen B, Marroquín BB, Schäfer D, Schulze R. Cytotoxicity of root canal filling materials to three different human cell lines. J Endod. 2000;26(12):703-7. doi:10.1097/00004770-200012000-00007

19. Ribeiro DA, Matsumoto MA, Duarte MA, Marques ME, Salvadori DM. In vitro biocompatibility tests of two commercial types of mineral trioxide aggregate. Braz Oral Res. 2005;19(3):183-7. doi:10.1590/S1806-83242005000300005

20. Ribeiro DA, Sugui MM, Matsumoto MA, Duarte MA, Marques ME, Salvadori DM. Genotoxicity and cytotoxicity of mineral trioxide aggregate and regular and white Portland cements on Chinese hamster ovary $(\mathrm{CHO})$ cells in vitro. Oral Surg Oral Med Oral Pathol Oral Radiol Endod. 2006;101(2):258-61. doi:10.1016/j.tripleo.2005.02.080

21. Gomes-Cornélio AL, Salles LP, Campos-da-Paz M, Cirelli JA, Guerreiro-Tanomaru JM, Tanomaru-Filho M. Cytotoxicity of Portland cement with different radiopacifying agents: a cell death study. J Endod. 2011;37(2):203-10. doi:10.1016/j.joen.2010.11.017

22. Singh NP, McCoy MT, Tice RR, Schneider EL. A simple technique for quantitation of low levels of DNA damage in individual cells. Exp Cell Res. 1998;175(1):184-91. doi:10.1016/0014-4827(88)90265-0

23. Camilleri J. The biocompatibility of modified experimental Portland cements with potential for use in dentistry. Int Endod J. 2008;41(12):1107-14. doi:10.1111/j.1365-2591.2008.01483.x

24. Amoroso-Silva PA, Marciano MA, Guimarães BM, Duarte MAH, Sanson AF, Moraes IG. Apical adaptation, sealing ability and push-out bond strength of five rootend filling materials. Braz Oral Res [Internet]. 2014 Aug 26 [cited 2016 Feb 17];28(1):1-6. Available from: http:// www.scielo.br/scielo.php?script=sci_arttext\&pid=S1806$83242014000100252 \& \operatorname{lng}=$ en\&nrm=iso\&tlng=en. doi:10.1590/1807-3107BOR-2014.vol28.0043

25. Mansur AA, Mansur HS. Preparation and characterization of $3 \mathrm{D}$ porous ceramic scaffolds based on portland cement for bone tissue engineering. J Mater Sci Mater Med. 2009 Feb;20(2):497-505. doi:10.1007/s10856-008-3612-1

26. Salles LP, Gomes-Cornélio AL, Guimarães FC, Herrera BS, Bao SN, Rossa-Junior C, et al. Mineral trioxide aggregatebased endodontic sealer stimulates hydroxyapatite nucleation in human osteoblast-like cell culture. J Endod. 2012;38(7):971-6. doi:10.1016/j.joen.2012.02.018

27. Modareszadeh MR, Di Fiore PM, Tipton DA, Salamat

N. Cytotoxicity and alkaline phosphatase activity evaluation of endosequence root repair material. J Endod. 2012;38(8):1101-5. doi:10.1016/j.joen.2012.04.014

28. Gandolfi MG, Shah SN, Feng R, Prati C, Akintoye $\mathrm{SO}$. Biomimetic calcium-silicate cements support differentiation of human orofacial mesenchymal stem cells. J Endod. 2011;37(8):1102-8. doi:10.1016/j.joen.2011.05.009

29. Lee SJ, Chung J, Na HS, Park EJ, Jeon HJ, Kim HC. Characteristics of novel root-end filling material using epoxy resin and Portland cement. Clin Oral Investig. 2013;17(3):1009-15. doi:10.1007/s00784-012-0782-5

30. Chang SW, Lee SY, Ann HJ, Kum KY, Kim EC. effects of calcium silicate endodontic cements on biocompatibility and mineralization-inducing potentials in human dental pulp cells. J Endod. 2014;40(8):1194-200. doi:10.1016/j.joen.2014.01.001

31. Tu MG, Chen YW, Shie MY. Macrophage-mediated osteogenesis activation in co-culture with osteoblast on calcium silicate cement. J Mater Sci Mater Med. 2015;26(12):276. doi:10.1007/s10856-015-5607-z

32. Gomes-Cornélio AL, Rodrigues EM, Salles LP, Mestieri LB, Faria G, Guerreiro-Tanomaru JM, et al. Bioactivity of MTA Plus, Biodentine and experimental calcium silicatebased cements in human osteoblast-like cells. Int Endod J. 2015 Nov 26 [cited 2016 Feb 17]. Available from: http:// onlinelibrary.wiley.com/doi/10.1111/iej.12589/abstract;j sessionid=A10B9DC41710A274DA102DCE9FEB2674.f02t0 4? systemMessage $=$ Wiley+Online+Library+will+be+una vailable+on+Saturday+27th+February+from+09\%3A00$14 \% 3 \mathrm{~A} 00+\mathrm{GMT}+\% 2 \mathrm{~F}+04 \% 3 \mathrm{~A} 00-09 \% 3 \mathrm{~A} 00+\mathrm{EST}+\% 2 \mathrm{~F}+17 \% 3-$ $\mathrm{A} 00-22 \% 3 \mathrm{~A} 00+\mathrm{SGT}+$ for+essential+maintenance.++Apologi es+for+the+inconvenience. doi:10.1111/iej.12589.

33. Berridge MV, Tan AS. Characterization of the cellular reduction of 3-(4,5-dimethylthiazol-2-yl)-2,5diphenyltetrazolium bromide (MTT): subcellular localization, substrate dependence, and involvement of mitochondrial electron transport in MTT reduction. Arch Biochem Biophys. 1993;303(2):474-82. doi:10.1006/abbi.1993.1311

34. Moghaddame-Jafari S, Mantellini MG, Botero TM, McDonald NJ, Nör JE. Effect of ProRoot MTA on pulp cell apoptosis and proliferation in vitro. J Endod. 2005;31(5):387-91. doi:10.1097/01.don.0000145423.89539.d7

35. Gorduysus M, Avcu N, Gorduysus O, Pekel A, Baran Y, Avcu F, et al. Cytotoxic effects of four different endodontic materials in human periodontal ligament fibroblasts. J Endod. 2007;33(12):1450-4. doi:10.1016/j.joen.2007.08.017

36. Franco R, Cidlowski JA. Apoptosis and glutathione: beyond an antioxidant. Cell Death Differ. 2009;16(10):1303-14. doi:10.1038/cdd.2009.107 
37. Eid AA, Gosier JL, Primus CM, Hammond BD, Susin LF, Pashley DH, et al. In vitro biocompatibility and oxidative stress profiles of different hydraulic calcium silicate cements. J Endod. 2014;40(2):255-60. doi:10.1016/j.joen.2013.07.009

38. Tice RR, Agurell E, Anderson D, Burlinson B, Hartmann A, Kobayashi $\mathrm{H}$, et al. Single cell gel/comet assay: guidelines for in vitro and in vivo genetic toxicology testing. Environ Mol Mutagen. 2000;35(3):206-21. doi:10.1002/(SICI)10982280(2000)35:3<206::AID-EM8>3.0.CO;2-J
39. Opačić-Galić V, Petrović V, Zivković S, Jokanović V, Nikolić B, Knežević-Vukčević J, et al. New nanostructural biomaterials based on actives silicate systems and hydroxyapatite: characterization and genotoxicity in human peripheral blood lymphocytes. Int Endod J. 2013;46(6):506-16. doi:10.1111/iej.12017

40. Kido HW, Oliveira P, Parizotto NA, Crovace MC, Zanotto ED, Peitl-Filho O, et al. Histopathological, cytotoxicity and genotoxicity evaluation of Biosilicate ${ }^{\circledR}$ glass-ceramic scaffolds. J Biomed Mater Res A. 2013;101(3):667-73. doi:10.1002/jbm.a.34360 